Municipal Bankruptcy Act ${ }^{57}$ such procedure is meaningless here since the bondholders have the only major financial interest..$^{8}$

These bonds may be sold to both private investors and the federal government. Until their soundness as investments is proved, however, it is probable that the national government will find it necessary to purchase the bulk of them. In fact, the government has provided a $\$ 500,000,000$ revolving fund for this purpose.59 The obvious result is that many of these projects are being entirely financed by federal money. In so far as the federal government has thus directly and indirectly financed the entire state program, a remarkable example of legal shadow-boxing is presented. Thus, like the direct federal program, many of the state developments are vulnerable to a change in Congressional sentiment.

Whether the bonds are owned privately or by the federal government, defaults would lead to an adverse-reaction toward state power activity in any form. A similar reaction to losses sustained by earlier state developments led to the present arbitrary constitutional debt limitations. The anomaly of a sovereign state imposing such limits upon itself emphasizes the need for proceeding on a sound basis to avoid a recurrence of a similar sentiment against worth-while state activity. Yet, the method used, revenue bond financing, is the one leaving creditors most vulnerable to the effects of general depressions. An unwholesome reaction can only be prevented by an integrated state program secured by the taxing power of the state. An adequate supply of private capital would be assured, thus guarding against changes in federal policy. South Dakota, by specific constitutional provision, ${ }^{60}$ has made the taxing power of the state available for electric power programs. While similar constitutional revision in other states may prove a tedious undertaking, it is necessary in order to assure the continued success of these essential projects. ${ }^{6 r}$

\title{
PROSPECTIVE WAR LEGISLATION
}

"A bill to prevent profiteering in time of war and to equalize the burdens of war and thus provide for the national defense, and promote peace" is the

${ }^{57} 50$ Stat. 653 (1937), I I U.S.C.A. § 40r (1937), upheld in Bekins v. Lindsey-Strathmore Irrigation Dist., 5 U.S. Law Week too4 (U.S. Sup. Ct., April 26, x938).

${ }^{58}$ General creditors would also sustain a loss, but their interests will probably be minute, compared to that of the bondholders.

59 Geffs and Hepburn, op. cil. supra note 34 .

${ }^{60}$ S.D. Const. art. $13, \S 12$, discussed in In re Opinion of the Judges, 43 S.D. 635,177 N.W. 812 (1920).

A similar attempt was made to amend the Wisconsin constitution. Wis. L. r93x, p. 923. A parliamentary maneuver in 1933 amended the proposal, requiring an additional legislative vote. Wis. L. I933, p. I28 r. Unfortunately, the amended proposal was defeated in 1935 .

or Existing projects could be encompassed by these revisions without losing present work relief benefits. 
promising title of proposed legislation called the May Bill. ${ }^{x}$ This bill, if passed, will grant to the next war president powers to do everything President Wilson did or was authorized to do and to extend their operation to affect classes of persons and property which were not directly affected during the last war. In the present era of international instability prospective war legislation affecting civilians will be passed, as it was passed before the last war. ${ }^{2}$ Problems suggested by the general question of prospective war legislation especially constitutional questions are worth discussing even if Congress is not seriously considering the May Bill.

Under the provisions of the May Bill, the President is empowered in time of war $^{3}$ to fix prices, ${ }^{4}$ to register, ${ }^{5}$ license, ${ }^{6}$ and control ${ }^{7}$ industry and commerce, to determine priorities in the filling of orders, ${ }^{8}$ to draft men ${ }^{9}$ and to take all necessary administrative measures necessary to accomplish the purposes of the act. ${ }^{\mathrm{Io}}$ The draft and compulsory registration sections rest frankly on presidential judgment or opinion. The penalties are clear-infringement of any presidential order is punishable by a $\$$ To0,000 fine or one year imprisonment, ${ }^{\text {II }}$ or both-but the classes to which they apply remain to be defined by the President. The President, it is fair to say, is uncontrolled by any objective standards and unguided by any proper expression of policy and in fact he must answer the questions that the legislature would ordinarily answer. A statement of policy setting forth the ends which the President must pursue in the exercise of his powers is not contained in any section, but is relegated to the legally ineffectual title. Yet it is important to note that the power to appropriate money to set up and run the executive machinery remains in Congress.

Legislation providing for control of civilian economic activity was unsystematic but plentiful during the World War. ${ }^{12}$ Control of resources, production, and distribution of food and fuel was placed in the hands of the President. ${ }^{13} \mathrm{He}$ was authorized-to cite the items that authors of the May Bill seem to be re-

× H.R. 9604, also called "the worst measure ever recommended for passage by a committee of Congress." Anderson, A Bill to Promote Dictatorship, I46 Nation 29I (I938). The May Bill is latest of a long line of bills concerning prospective war legislation. Editorial, Blueprint Dictatorship, New York Times, April ro, 1938.

${ }^{2}$ National Defense Act, 39 Stat. 2I3 (rgI6); Naval Emergency Fund Act, 39 Stat. II93 (I9I7); Army Appropriation Act, 39 Stat. 649 (rgI6); Joint Resolution (control of railroads) 39 Stat. 387 (I9I6); Act to Regulate Radio Communication, 37 Stat. 303 (Igr2).

$3 \S 8$.

$4 \S \AA, 2$

$5 \S 5$.

Io $\S 9$. By $\S \mathrm{II}$, the Treasury department is required to present to Congress in advance a plan of taxation "which shall absorb all profits above a fair normal return."

II $\S$ IO.

12 See generally Berdahl, War Powers of the Executive in the United States 203-212 (I920). ${ }^{23}$ Fuel and Food Act, 40 Stat. 276 (I9I7). 
enacting too broadly-to license certain processes, ${ }^{\mathrm{x} 4}$ to take over and operate named productive and distributive agencies engaged in the food and fuel industries, ${ }^{15}$ to requisition, ${ }^{16}$ fix prices of, ${ }^{17}$ and to buy and sell specific kinds of articles. $^{18}$ The President was authorized, whenever public safety required, to regulate or prohibit exports ${ }^{19}$ and imports. ${ }^{20} \mathrm{He}$ could place orders for army ${ }^{2 \mathrm{x}}$ and navy $y^{22}$ supplies which took automatic precedence over all other orders received by the manufacturers, and if preference were refused, the President was authorized to take immediate possession of the plant. The Council of National Defense, set up by Congress, ${ }^{23}$ created the War Industries Board ${ }^{24}$ which became an administrative agency, along with the Food and Fuel Administrations, through which the President exercised most of his powers. The War Industries Board, however, existed on presidential authority alone; yet it fixed prices, ${ }^{25}$ determined priorities of delivery, developed new sources of supplies, bought and sold for the Allies and the United States. Its "requests" were sanctioned by the presidential powers to withhold fuel and transportation. Control of property in the strict sense as distinguished from economic activity was perhaps more stringent. ${ }^{26}$ Both enemy ${ }^{27}$ and American property ${ }^{28}$ could be and were confiscated. ${ }^{29}$ The President took over and operated the railroads on statutory authority, ${ }^{30}$ after private control had failed to meet the requirements of war. Enemy, neutral, and American shipping and marine construction were brought under presidential control. ${ }^{3 x}$ The President assumed control of radio stations,

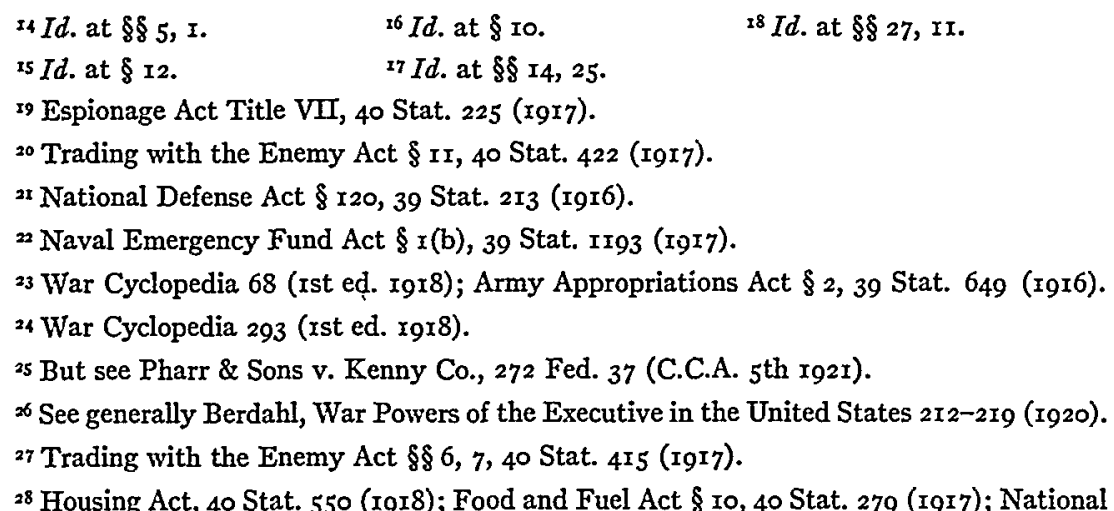
Defense Act $\S \S$ I20, I23, 39 Stat. 213, 215 (IgI6); Naval Emergency Fund Act, $\S$ I(b), 39 Stat. II93 (IgI6).

${ }^{29}$ Compensation was awarded to persons not enemies. Seaboard Air Line Ry. Co. v. United States, 26I U.S. 269 (r922); United States v. New River Collieries Co., 262 U.S. 34I (1922); Cummings v. Deutsche Bank und Discontogesellschaft, 300 U.S. II5 (1937); Cummings v. Isenberg, 89 F. (2d) 489 (App. D.C., 1937), cerl. denied, 301 U.S. 682 (1937). For legislative history of Trading with the Enemy Act, see 50 U.S.C.A., Appendix, $\$ \S I-24$.

${ }^{30}$ Joint Resolution 39 Stat. 387 (19r6); Army Appropriations Act \& 2, 39 Stat. 649 (Igr6); Railway Control Act 40 Stat. 45I (IgI8).

${ }^{35}$ Shipping Board Act 39 Stat. 728 (I9I6); Joint Resolution 40 Stat. I82 (I9I7); Urgent Deficiency Act 40 Stat. 459 (Igr8). 
telephone, telegraph, and cable systems. ${ }^{32}$ Perhaps the most severe control of all was over persons; the President was authorized to draft all male citizens between twenty-one and thirty into military service. ${ }^{33}$ Finally, for the successful prosecution of the war, the President was authorized to redistribute and consolidate functions of all administrative agencies. ${ }^{34}$

The lack of specific enumeration and definition in the May Bill provides the chief contrast between the bill and the World War legislation. The powers granted in the May Bill to the President are so uncontrolled and are directed at persons and property defined so generally that the bill comes close to being a complete incongruity in a democratic country. The powers granted to the President by World War legislation in an unsystematic fashion were limited to specific situations and directed at defined classes of persons and property. It is apparent, however, that during the last war Congress was too specific or too slow to give the powers the President needed, for through the War Industries Board the President exercised powers that were never authorized by Congress in order to meet situations which Congress did not foresee. To place a President in a position where he must exercise powers not authorized by Congress in order to meet situations which Congress did not happen to foresee is dangerous. ${ }^{35}$ It is less dangerous to give the President all the powers found necessary in the last war under some general standard and policy prescribed by Congress and interpreted by the courts. This minimum of control over the President is desirable and necessary, as an examination of the presidential war powers will demonstrate.

There are perhaps three sources of the presidential war power. It is ordinarily said that the President must derive his power from the Constitution and

${ }^{22}$ Act to Regulate Radio Communication $\S 2,37$ Stat. 303 (I9r2); Joint Resolution, 40 Stat. 904 (Igr8).

33 Selective Draft Act $\$ 2,40$ Stat. 77 (1917).

${ }^{34}$ The Overman Act, 40 Stat. 556 (I9I7). With a single exception, United States v. Cohen Grocery Co., 255 U.S. 8I (1920), the World War legislation, when contested, was held enforcible. Food and Fuel Act: Highland v. Russell Car \& Snowplow Co., 279 U.S. 253 (I928); Jacob Ruppert Inc. v. Caffey, 25x U.S. 264 (rgrg); Espionage Act: Milwaukee Pub. Co. v. Burleson, 255 U.S. 407 (1920); Abrams v. United States, 250 U.S. 616 (I919). Railway Control Act: Northern Pacific Ry. Co. v. North Dakota, 250 U.S. 135 (I918); Public Service Commission v. N.Y. Cent. Ry. Co. 230 N.Y. 149, x29 N.E. 455 (1920). Trading with the Enemy Act: Salamandra Ins. Co. v. New York Life Ins. Co., 254 Fed. 852 (S.D.N.Y. 1918). Control of Telephone Cable System: Read v. Central Union Tel. Co., 2I3 Ill. App. 246 (Igrg); Commercial Cable Co. v. Burleson, 255 F. 99 (IgI9), dismissed as moot, 250 U.S. 360 (IgI8). War Industries Board: See United States v. Kraus, 33 F. (2d) 406 (C.C.A. 7th I929); United States v. Farland, $x_{5}$ F. (2d) 823 (C.C.A. 4th 1926). Selection Draft Act: The Selective Draft Law Cases, 245 U.S. 366 (xgI $)$. See generally Berdahl, War Powers of the Executive in the United States $167-219$ ( 1920 ); Walsh, War Powers of the President, 24 Case \& Com. 297 (I9I7).

35 Lincoln went further in this respect than Wilson. Randall, Constitutional Problems under Lincoln $523-530$ (r926). 
from Congress. ${ }^{36}$ As to these two sources, implication and broad construction have been catalysts in the constant expansion of presidential war power. ${ }^{37}$ Emergency, calling for quick action and resulting in fait accompli, can be regarded as a third source of power..$^{8}$ It cannot be doubted that some executive war orders in emergency situations have been presidential legislation. ${ }^{39}$

As a restriction on presidential war power, the Fifth Amendment and other articles of the Bill of Rights are not extinguished by war ${ }^{40}$ and remain, at least in a war-weary state of public opinion, a potential check on the President. The war power of the federal government in respect to non-combatants has been viewed as vast police power. ${ }^{4 \mathrm{I}}$ It is true that in time of war high public interest outweighs individual rights; idolatry of militarism demands harsh sacrifices from iconoclasts who will speak their minds and will resist property seizures, protected only by vitiated rights of free speech, ${ }^{42}$ press, ${ }^{43}$ and due process of law. 44 But in the one case of unconstitutionality of world war legislation, it was the Fifth Amendment that was successfully invoked. In United States v. Cohen Grocery Co.45 the terms of Section 4 of the Food and Fuel Act, "unjust and unreasonable rate or charge in handling or dealing with necessaries," were held too indefinite to be within the requirement of due process in an indictment against the defendant for profiteering. To remove the same objections to presidential orders under the May Bill it seems clear that Congress or the President will have to enumerate and define the persons and property to which the penal sanctions are directed. The Fifth Amendment, however, will directly reach only presidential orders ${ }^{46}$ through which the act will

${ }^{36}$ Taft, Our Chief Magistrate I39-I40 (I925); Randall, Constitutional Problems under Lincoln 35 (xg26). For constitutional war powers of the President, see U.S. Const, art. $2, \S \mathrm{I}$. cl. I; $\S 2$, cl. I. For related powers see U.S. Const. art I, § 2, cl. r, cl. 2; § 3; § 7, cl. 2, 3; art. 4, § 4. For Congressional war powers, see Const. art. I, $\$ 8$, cl. II-r 8 .

37 Berdahl, War Powers of the Executive in the United States 265-270 (I920).

${ }^{8}$ Randall, Constitutional Problems under Lincoln 35-36 (I926); Berdahl, War Powers of the Executive in the United States I9 (I920).

39 Randall, Constitutional Problems under Lincoln 37-39 ( 1926$)$.

${ }^{40}$ Hamilton v. Kentucky Distilleries Co., $25 x$ U.S. 46 (Igrg); Davis v. Newton Coal Co., 267 U.S. 292 (1924); Ex parte Milligan, 4 Wall (U.S.) 2 (r866); Ballantine, The Effect of War on Constitutional Liberty 24 Case \& Com. 3 (I9I7).

4t Hamilton v. Kentucky Distilleries Co., 25 I U.S. I46 (Igrg).

${ }^{2}$ Pierce v. United States, 252 U.S. 239 (rgrg).

43 Schaefer v. United States, 25I U.S. 466 (IgI9).

${ }_{44}$ Salamandra Ins. Co. v. New York Life Ins. Co., 254 Fed. 852 (S.D.N.Y. Igr8). See supra, note 34 .

${ }_{45} 255$ U.S. 8I (1920). The effect of this decision was extended to civil cases, HandleyMack Co. v. Godchaux Sugar Co., 2 F. (2d) 435 (C.C.A. 6th I924), but did not nullify other clauses of $\S 4$ or other sections of the act. Fannon v. United States, 276 Fed. Iog (C.C.A. 9 th I921); Baird v. United States, 279 Fed. 509 (C.C.A. 6th I922).

${ }^{46}$ Exposure to liability by proclaimed presidential order is no worse than the kind of subsequent liability which juries impose. As Mr. Justice Holmes has said in another connec- 
operate, not the act itself. These orders will raise the question of how such extensive power can be delegated to the President. Some recent decisions suggest the doctrine against delegation of legislative powers is another potential check on the presidential war power.

The principle that legislative power may not be delegated by Congress to the President is founded on the separation of powers, which in turn is founded not on what the Constitution says, but is implied from what it does in separating grants of legislative, executive and judicial powers. ${ }^{47}$ The doctrine ${ }^{48}$ yields to practical necessity both on the separation of powers element and on the definition of what is legislative power. For example, complete separation of powers is not found even in the Constitution.49 Moreover, some powers delegated to Congress by the Constitution can be redelegated. Congress, Chief Justice Marshall once suggested, may have powers such as regulating federal court procedure, which are not legislative, but something "of less interest," and are therefore delegable. ${ }^{\circ}$ Congress can set up a rule of law and make its operation contingent upon ascertainment of a condition or state of facts by the President ${ }^{5 x}$ and can give the President or other executive agency power to prescribe rules and regulations under the guidance of a standard and in pursuance of a policy declared by Congress. ${ }^{52}$

In the emergency of the World War, delegations of power to the President were hardly serious issues. The power of the President to draft men was summarily upheld. ${ }^{33}$ The startlingly judicial system of draft boards to administer selections was said to be "essentially executive." 54 Power in the Secretary of War to set the zone around military camps within which keepers of brothels would be subjected to criminal penalties was upheld.55 Other powers to issue

tion, " . . . the law is full of instances where a man's fate depends upon his estimating rightly, that is, as the jury subsequently estimates it, some matter of degree . . ." Nash v. United States, 229 U.S. 373,377 (rg12).

47 U.S. Const., arts I, II, III. There is nothing new about the principle of separation of powers. Aristotle, Politics Bk. VI, c. 2; Montesquieu, Spirit of the Laws, Bk. XI, c. 6.

${ }^{8}$ If that old common law maxim, delegata potestas non potest delegari, $2 \mathrm{Co}$. Inst. 579 , is translated, interspersed, and rearranged in this fashion: power delegated by the Constitution to Congress cannot be delegated by Congress to the President, the rules about delegation of powers become intelligible, if not convincing. Duff and Whiteside, Delegata Potestas Non Potest Delegari, $x_{4}$ Corn. L.Q. I68, I73-rg6 (I929).

49 Presidential veto power, for example, is legislative, U.S. Const. art. I, $\S 6$, cl. 3 .

so Wayman v. Southard, to Wheat. (U.S.) I, 42-47 (1825).

51 Hampton \& Co. v. United States, 276 U.S. 394 (r928).

52 United States v. Grimaud, 220 U.S. 506 (I9II); Buttfield v. Stranahan, I92 U.S. 470 (rgo3).

53 The Selective Draft Law Cases, 245 U.S. 366 (IgI 7); Sugar v. United States, 252 Fed. 74 (C.C.A. 6th I9r8); Frank v. Murray, 248 Fed. 865 (C.C.A. 8th Igr8).

54 United States v. Stephens, 245 F. 956 (D.C. Del. I9I7), aff'd, 247 U.S. 504 (I9I7).

ss McKinley v. United States, 249 U.S. 397 (xgI8); United States v. Casey, 247 Fed. 362 (D.C. Ohio IgI8). 
negotiable scrip ${ }^{56}$ and to sell enemy property 57 were upheld. Similar delegations of power by state legislatures were affirmed..$^{8}$ In most of the World War legislation the standards and policies set up by Congress to guide executives were either expressed with definiteness or the powers delegated were restricted to a particular situation or named class of persons or property.

How definite the standard and how explicit the policy are problems that have become acute in post-war decisions. The first section of the National Industrial Recovery Act 59 in light of the war cases would appear sufficiently definite $^{60}$ to declare a policy of Congress in a period of economic emergency. But that declaration was said, in Panama Refining Co. v. Ryan" to "declare no policy and define no standard," and was rejected in Schechter Poultry Corp. v. United States ${ }^{62}$ as neither a standard nor a policy sufficient to uphold the constitutionality of the delegation of power to the President to approve and give the force of law to industrial codes. Although almost identical legislative aims had been set out in earlier laws, and, singly considered, were adequate, ${ }^{63}$ yet this combination appeared to attempt too much despite economic emergency. The combination of powers exercised in the last war, re-enacted in a single piece of legislation, may be open to the same fatal objection. In normal times, however, the requirement of definite standard and explicit policy has been more lenient. ${ }^{6}$ Indeed, it has been noted that the National Industrial Recovery Act was the first act of Congress declared unconstitutional as an improper delegation of legislative power. ${ }^{65}$

There may be a distinction between war and economic emergency, ${ }^{66}$ but

${ }^{56}$ Security Nat'l Bank v. People's Bank, 287 Mo. 464, 230 S.W. 87 (I92I).

s7 United States v. Chemical Foundation, 272 U.S. I (r926).

${ }^{8}$ People ex rel. Doscher v. Sisson, 222 N.Y. 387 , I18 N.E. 789 (rgr8).

${ }^{59} 48$ Stat. 195 (I933).

${ }^{6}$ Section 1 reads in part: ". . . . to remove obstructions to the free flow of interstate and foreign commerce which tend to reduce the amount thereof .... to provide for the general welfare by promoting the organization of industry .... to induce and maintain united action of labor and management .... to eliminate unfair competitive practices, to promote the fullest possible use of the productive capacity of industries, to increase the consumption of industrial and agricultural products by increasing purchasing power, to reduce unemployment, to improve standards of labor, and otherwise rehabilitate industry, and to conserve natural resources."

$$
\text { 6r } 293 \text { U.S. 388, 43I (1934). } 62295 \text { U.S. } 495 \text { (r934). }
$$

${ }_{63}$ For example, the River and Harbor Act $\S 30$, Stat. II53 (I899), giving the Secretary of War power to require alteration of any bridge he believes "an unreasonable obstruction to free navigation ...." was held a valid delegation of power. Union Bridge Co. v. United States, 204 U.S. 364 (I906).

64 See Hampton \& Co. v. United States, 276 U.S. 394 (I928); New York Securities Corp. v. United States, 287 U.S. I2 (1932); Mahler v. Eby, 22 I U.S. I94 (I9I0); Mutual Film Corp. v. Industrial Commission, 236 U.S. 230 (19I4).

${ }^{65}$ Note 79 L. Ed. 474,487 , n. 47 (1934).

${ }^{66}$ Emergency does not create, but furnishes the occasion for the exercise of power. Home Building \& Loan Ass'n. v. Blaisdell, 290 U.S. 398, 425-426 (1933). See Avent v. United States, 266 U.S. I27 (I924). 
the Court has not distinguished between war-time and peace-time delegations of power. ${ }^{67}$ The Court, it is believed, will have a choice; it can follow either the looser war decisions or the stricter N.R.A. decisions. It is unquestionable that if the Court follows the reasoning of Schechter Poultry Corp. v. United States and Panama Refining Co. v. Ryan, legislation like the May Bill will be unconstitutional, except insofar as it is made specific, because it does not sufficiently control the discretion of the President. It is quite possible that in a war situation the Court will confess to an error in judicial statesmanship. ${ }^{68}$ Otherwise, Congress will be hard put to it to delegate enough power to the President for the requirements of war. How to fight a successful war yet avoid the evils of dictatorship is a political problem which intelligent legislation can help solve.

The possibility of dictatorship on excuse of war, a danger common to all democracies, will be accentuated by careless prospective war legislation in the United States where the President holds a whip hand over foreign relations. War can be declared only by Congress, ${ }^{69}$ but it is beyond question that the President as a matter of practical politics can force the country into war. ${ }^{70}$ War can end only by treaty ${ }^{7 x}$ which the President must negotiate. ${ }^{72}$ The risk of prospective war legislation giving immense power should be taken, if at all, only after widespread debate and consideration. It may be desirable to advertise what the people at home ${ }^{73}$ and potential adversaries abroad may expect in event of another war. It is arguable that democracies must be able in event of war to do everything the modern dictatorships can do-and do it first. That military organization must result in dictatorship is a proposition denied by American experience. ${ }^{74}$ The war presidents have so far resisted temptations of autocracy and have secured Congressional assent or ratification on questions of powers and policies. 75

${ }_{67}$ Cases dealing with delegation of peace-time powers have been cited in cases upholding delegations of war-time powers. See Field v. Clark, 143 U.S. 649 (I89r), cited in The Selective Draft Law Cases, 245 U.S. 366,389 ( $\mathrm{Igr} 7$ ); United States v. Chemical Foundation, 272 U.S. I, I2 (I926).

${ }^{6}$ Since the kind of legislation in question deals with internal control of civilians, it seems unlikely that the delegation of power issue is irrelevant as has been held in regard to legislation on external affairs. United States v. Curtiss-Wright Export Corp., 299 U.S. 304 (1936).

69 U.S. Const., art I, $\$ 8$, cl. rr. $7^{70}$ Taft, Our Chief Magistrate 94 (r925).

${ }_{7 x}$ Hamilton v. Kentucky Distilleries Co., 251 U.S. I46 (IgI9).

$7 z$ U.S. Const. art. II, $\$ 2, \mathrm{cl}$. 2. The World War was terminated, however, not by President Wilson's treaty, which was repudiated, but by Congress. Joint Resolution, 4I Stat. Ir59 (I92I).

${ }_{73}$ Anderson, A Bill to Promote Dictatorship, I46 Nation 29I (I938).

74 Washington was offered dictatorship; Lincoln exercised one; Wilson, it was seriously suggested by Senator Warren G. Harding, should have been made a dictator; yet the country has remained a democracy. Berdahl, War Powers of the Executive in the United States 18, 203 (I920).

75 Randall, Constitutional Problems under Lincoln 38, 55-59 (1926); Berdahl, War Powers of the Executive in the United States 204-205 (I920). The ratification cures the illegality of prior acts of the President. Prize Cases, 2 Black (U.S.) 635, 670-67I (I862). 
Perhaps the presidential war measures could best be controlled, yet meet the requirements of practicality in war administration by offsetting presidential discretion with threat of subsequently exercised judicial discretion both operating under policies set forth by Congress. Thus the powers to fix prices, to requisition, to take over and operate, to draft, to register citizens and civilian organizations, to license, and to create all necessary administrative agencies ought to be directed to specific situations, objects, classes of persons and property so far as Congress is in good faith able to foresee the contingencies of war. But since Congress cannot foresee all the possible contingencies, the same powers should also be delegated generally to the President, to be exercised only in situations not prescribed by Congress, each accompanied by a provision that all determinations and orders of the President must be reason$a b l y$ adapted to an equalization of the burdens of the successful prosecution of the war. ${ }^{76}$ Reasonableness is a standard which the courts recognize and understand. It is a standard which has been imposed upon a statute by implication. ${ }^{77}$ As a standard it has a flexibility which may be useful in dealing with the peculiar problem of war legislation. It will compel the President to justify his determinations and orders in such a way as to make them judicially palatable. ${ }^{78}$ The threat that they may turn out to be unpalatable is in itself a limitation on the executive power. So the threat of unenforcibility of judgments and decrees during war frenzy will temper the judicial discretion. ${ }^{79}$ On the other hand the Court would be emboldened by a war-weary public opinion ${ }^{80}$ to check the President within the latitude of the term, "reasonable."

It is apparent that a challenge of constitutionality before war is declared may be procedurally impossible because such legislation becomes operative only on declaration of war and no person will be in a position to generate a case or controversy. A test of constitutionality may not be possible even under the Federal Declaratory Judgment Act ${ }^{8 \mathrm{r}}$ in view of the strong dicta of the Supreme Court against purposeful suits looking to a test of constitutionality ${ }^{82}$ and the

\footnotetext{
$7^{6}$ As policies, equalization of burdens seems inevitable and successful prosecution selfevident.

77 Sherman Anti-Trust Act, 26 Stat. 209 (I890), x5 U.S.C.A. \$ $\mathrm{x}$; Standard Oil Co. v. United States, 221 U.S. I (IgII).

${ }^{78}$ The Fifth Amendment will require specificity of persons and property sought to be affected. United States v. Cohen Grocery Co., 255 U.S. 8I (I920).

${ }^{79}$ See Ex parte Merryman, Fed. Cas. No. 9, 487 (18ז6); Randall, Constitutional Problems under Lincoln, I I8-I39, I6r-I62 (I926).

${ }^{80}$ For view that public opinion is the real limitation on delegation of powers, see Goodnow, Administrative Law in the United States 55-56 (I905).

${ }^{8 x} 28$ U.S.C.A. $\$ 400$ (I934).

82 Hughes, C.J., and Brandeis, J., concurring, Ashwander v. T.V.A., 279 U.S. 288, 325, 346 (1935). Cf. Willing v. Chicago Auditorium Ass'n., 277 U.S. 274 (1928); Liberty Warehouse v. Grannis, 273 U.S. 70 (Ig27); Nashville, C. \& St. L. Ry. v. Wallace, 288 U.S. 249 (I932). See Const., Art. III, \& 2, cl. I; Aetna Life Ins. Co. v. Haworth, 300 U.S. 227 (1936); Borchard, Justiciability, 4 Univ. of Chi. L. Rev. I (I936).
} 
indecisiveness of the lower federal courts on the question..$^{83}$ After a declaration of war a fair test of constitutionality may be politically impossible. It is therefore important that Congress draft an act with some safeguards, because they may be the only safeguards.

To place much faith in legal tests of constitutionality of any war legislation is improvident at any time and surely a delusion after war has been declared. But the term, "reasonable," will allow the judiciary a check if that resource becomes politically advisable. Under the same political circumstances Congress too has a check, for Congress still holds the purse strings. It cannot appropriate money for war purposes for more than two years at a time. ${ }^{84}$ The May Bill contains provision for taxation ${ }^{85}$ but not for appropriation. This powerful democratic weapon in the hands of parliamentary bodies, even as a check upon the war power of the executive, should not be overlooked. Lincoln did appropriate money without the assent of Congress, but Congress nevertheless ratified his use of Treasury funds. ${ }^{86}$ Congress probably could appropriate a large sum contingent upon declaration of war. ${ }^{87}$ But aside from the uselessness of so doing, Congress should retain its power to appropriate and to cut off appropriations as a fundamental check upon the war power of the President.

\section{PAROL EVIDENCE AND THE BONA FIDE PURCHASER}

No aspect of the law has presented more confusion than the parol evidence rule as applied to the interpretation of written instruments. The prevailing common law rule, which is still followed in many jurisdictions, is the so-called "clear meaning" rule, which permits parol evidence to explain the terms of the written instrument only where the terms are ambiguous. ${ }^{\mathrm{I}}$ In contrast, the "liberal" rule permits evidence to explain the intended meaning of the words of the instrument even where the words are unambiguous as used in their ordinary

${ }^{83}$ See Fosgate Co. v. Kirkland, I9 F. Supp. I52 (S.D. Fla., I937). Cf. S.E.C. v. Electric Bond \& Share Co., 18 F. Supp. I3 I (S.D.N.Y., 1937); Boggus Motor Co. v. Onderdonk, 9 F. Supp. $95 \circ$ (S.D. Tex., 1935). As to contesting tax statutes, see amendment, 49 Stat. Io27 (I935); Beeland Wholesale Co. v. Davis, 88 F. (2nd) 447 (C.C.A. 5th I937).

Perhaps it is not preposterous to assert that the chief of staff of the army, or the chairman of the committee on military affairs could bring a mandamus against the Secretary of Treasury to compel him to submit to Congress a plan of war taxation in accordance with a requirement like Section Ir of the May Bill (note 9 supra). This controversy passes the area of the moot case and the advisory opinion. $36 \mathrm{Col}$. L. Rev. Ir69 (1936). It will lead to a decision which will prevent parties from acting or refusing to act at their peril. 49 Harv. L. Rev. I35I (1936). It will be difficult to confine the decision to the narrow mandamus issue; the purpose of the taxation requirement will be in question, and the answer will involve the validity of the entire bill.

\footnotetext{
84 Const., art. I, § 8, cl. I2. $85 \&$ II.

${ }^{86}$ Berdahl, War Powers of the Executive in the United States Iro-III (1920).

${ }^{87}$ See United States v. Butler, 297 U.S. I (I935).

${ }_{5} 5$ Wigmore, Evidence $\$ 246$ I (2d ed. I923).
} 